\title{
NOTAS SOBRE A ESCOLA DOS TUPINAMBÁ DE OLIVENÇA/BA
}

\author{
NOTES ABOUT THE TUPINAMBÁ'S SCHOOL FROM OLIVENÇA/BA
}

\section{NOTAS SOBRE LA ESCUELA DE TUPINAMBÁ OLIVENÇA/BA}

José Valdir Jesus de Santana ${ }^{1}$, Clarice Cohn ${ }^{2}$

RESUMO

Neste artigo pretendemos demonstrar, a partir de pesquisa etnográfica que temos realizado desde 2011 junto ao povo indígena Tupinambá de Olivença/BA, como o "estar na cultura" e "tornar-se forte na cultura" vão sendo produzidos a partir da escola e das relações que ela possibilita e articula, tanto interna quanto externamente, no movimento que multiplica a escola pelo Território Indígena, em especial pelas áreas de retomadas. A escola tem sido o lugar de produção de cultura, de pessoa, de parente, de "retomada" da tradição, de defesa do território e de atualização do que significa, para este povo, "estar na cultura". Nesse sentido, "estar na cultura" para os Tupinambá se traduz no processo de construir coletividades.

PALAVRAS-CHAVE: Educação escolar. Estar na cultura. Povo indígena Tupinambá

\begin{abstract}
In this article we aim to demonstrate, from the ethnographic research that we have carried out since 2011 with the Tupinambá indigenous people from Olivença/BA, as "being in culture" and "becoming strong in culture" are produced from school and relationships that it enables and articulates, both internally and externally, in the movement that multiplies the school through the Indigenous Territory, especially in the areas of resumption. The school has been the place of culture production, of person, of relative, of tradition "recovery", of defending the territory and of updating what it means for these people to "be in the culture". Following this thinking, "being in the culture" for the Tupinambá translates into the process of building collectivities.
\end{abstract}

KEYWORDS: Schooling. Being in culture. Tupinambá indigenous people.

\section{RESUMEN}

En este artículo nos proponemos a demostrar, a partir de la investigación etnológica que tenemos realizado desde 2011 con el pueblo indígena Tupinambá de Olivença/Ba, como el "estar en la cultura" y "convertirse fuerte en la cultura" van siendo producidos a partir de la escuela y de las relaciones que ella posibilita y articula, tanto interna cuanto externamente, en el movimiento que multiplica la escuela por el Territorio indígena, en especial por las áreas de recuperación. La escuela han sido el sitio de producción de cultura, de persona, de pariente, de "recuperación" de la tradición, de defesa del territorio y de actualización de lo que significa, para este pueblo, "estar en la cultura". En este sentido, "estar en la cultura” para los Tupinambás traduce en el proceso de construir colectividades.

PALABRAS CLAVE: Educación escolar. Estar en la cultura. Pueblo indígena Tupinambá.

\footnotetext{
${ }^{1}$ Doutor em Antropologia Social - Universidade Federal de São Carlos (UFSCAR) - São Carlos, SP. Brasil. Professor adjunto - Universidade Estadual do Sudoeste da Bahia (UESB) - Vitória da Conquista, BA. Brasil. E-mail: santanavaldao@yahoo.com.br

2 Doutora em Antropologia Social - Universidade de São Paulo (USP) - São Paulo, SP. Professora adjunta Universidade Federal de São Carlos - Universidade Federal de São Carlos (UFSCAR) - São Carlos, SP. Brasil. E-mail: clacohn@gmail.com

Submetido em: 16/12/2016 - Aceito em: 10/03/2018
}

(C) ETD-Educação Temática Digital Campinas, SP $\quad$ v.20 $\quad$ n.3 $\quad$ p. 718-740 jul./set. 2018




\section{INTRODUÇÃO}

Em nossa tese de doutorado, defendida no Programa de Pós-Graduação em Antropologia Social da Universidade Federal de São Carlos, buscamos compreender como e por que os Tupinambá de Olivença/BA fazem escola e do como esta tem se tornado central na produção de pessoas "fortes na cultura", na atualização e produção de parentesco, aparentamento e no "estar na cultura", como costumam afirmar. Nesse sentido, interessounos pensar como o "estar na cultura" e tornar-se "forte na cultura" vão sendo produzidos a partir da escola e das relações que esta possibilita e articula, tanto interna quanto externamente, através do movimento que multiplica a escola pelo Território Indígena, em especial pelas "áreas de retomadas". Para os Tupinambá, tornar-se "forte na cultura" implica em compartilhar memórias, afetos, em estar juntos (VIEGAS, 2003, 2007), em produzir cultura e, para que isso ocorra, a escola tem se tornado central; do mesmo modo, como dizem os Tupinambá, a escola tem sido, ademais, o "lugar da cultura", processo que tem sido observado em outros contextos, como nos demonstra Weber (2006) em sua etnografia sobre os Huni Kuin ${ }^{4}$ e Mainardi (2010a, 2010b) sobre os Tupi Guarani.

A garantia legal de escolas indígenas específicas, diferenciadas e interculturais, conforme legislação em vigor, que respeite as manifestações culturais, organizações sociais, políticas e processos próprios de ensino e aprendizagem, foi uma conquista de direito que se consolida desde a Constituição Federal de 1988 e que se contrapõe à vocação histórica da escolarização dos povos indígenas, catequética e civilizatória. Propondo uma escola que permita aos povos manter, valorizar e reforçar suas culturas e construir sua autonomia, a escola indígena vem se constituindo, ao longo das últimas décadas, em uma política cultural para estes povos. Por ela, ou através dela, é proposto o regaste das culturas e a construção de identidades; e, cada vez mais, nelas se propõem partes diferenciadas como um currículo cultural e indígena que complementa o currículo dos conhecimentos ditos universais (COHN, 2014).

\footnotetext{
3 "Retomadas" consistem em processos de recuperação, pelos indígenas, de áreas por eles tradicionalmente ocupadas, no interior das fronteiras da Terra Indígena - TI, e que se encontravam em posse de não índios. São ações encabeçadas por um cacique, algumas de suas lideranças e famílias indígenas que ao identificarem uma área improdutiva ou abandonada dentro da TI investem na ocupação territorial da mesma (MEJÍA LARA, 2012; ALARCON, 2013; ROCHA, 2014).

${ }^{4}$ Nesse texto, diante do limite de páginas, não é possível apresentar a densidade dos dados produzidos durante a pesquisa de doutorado, que resultou na etnografia intitulada "A letra é a mesma, mas a cultura é diferente": A escola dos Tupinambá de Olivença (2015). Todavia, interessa-nos apresentar aspectos que consideramos importantes e que, no limite, sinalizam para os modos como os Tupinambá de Olivença têm produzido sua escola.
}

$\begin{array}{llllll}\text { (C) ETD- Educação Temática Digital } & \text { Campinas, SP } & \text { v.20 } & \text { n.3 } & \text { p. 718-740 } & \text { jul./set. } 2018\end{array}$


Pesquisadores como Grupioni (2008, 2013), Cohn (2005, 2014), Cohn e Santana (2013, 2016), Bergamashi (2012), Lopes da Silva (2001), Tassinari (2008), Ferreira (2001), D’Angelis (2012), Tassinari e Cohn (2012), Paladino e Almeida (2012), Paladino e Czarny (2012), Souza (2013), dentre outros, já nos demonstraram como vão se constituindo as políticas de educação escolar indígena no Brasil, em diferentes períodos de nossa história e do como, atualmente, tais políticas têm sido implementadas e apropriados pelos povos indígenas, em um contexto em que termos como especificidade, diferença e interculturalidade orientam tais políticos e distintos projetos de educação. Portanto, compreender como cada povo indígena tem produzido suas escolas é de fundamental importância, posto que, como já nos advertiu Sahlins (2004, p. 184) "nenhum objeto, nenhuma coisa existe ou tem movimento numa sociedade humana exceto pela significância que os homens the possam atribuir". Nesse sentido, são muitos os sentidos e significados que os povos indígenas, a exemplo dos Tupinambá, têm atribuído à escola, através de suas "políticas culturais", como propõe Carneiro da Cunha (2014). A etnografia (PEIRANO, 1995; LOPES DA SILVA, 2001; COLLET, 2006), portanto, se torna fundamental para a compreensão desses processos.

\section{OS TUPINAMBÁ DOS DIAS ATUAIS: BREVES CONSIDERAÇÕES}

De acordo com dados da Secretaria Especial de Saúde Indígena - SESAI (Bahia), em 2011, os Tupinambá contabilizavam 4.486 indivíduos configurando a segunda maior etnia no Estado. Os Tupinambá estão distribuídos em diferentes comunidades que estão dispostas em uma extensão aproximada de 47 mil hectares e que compreende os municípios de Ilhéus, Buerarema e Una. Estes limites geográficos já foram reconhecidos como Terra Indígena e abarcam ambientalmente paisagens muito distintas que se estendem desde a costa litorânea até a região serrana de mata atlântica (ROCHA, 2014).

Olivença, área próxima ao litoral, fora no passado um antigo aldeamento jesuíta, denominado de Nossa Senhora da Escada ${ }^{5}$, que preserva até hoje a arquitetura quadricular e a igreja construída em meados de 1700. A maioria das famílias de nativos foi expulsa da vila durante a primeira metade do século $X X$, mas algumas conseguiram permanecer e outras acabaram voltando posteriormente, sendo que hoje se constata a presença tanto de moradores indígenas quanto de não indígenas (MARCIS, 2004; VIEGAS, 2007; ROCHA, 2014).

\footnotetext{
${ }^{5}$ Nossa Senhora da Escada foi elevada à condição de freguesia, “cujo termo abarcava os limites da Vila Nova de Olivença, criada por Carta Régia em 1758, embora seu estabelecimento tenha sido concretizado pelo ouvidor Luís Freire de Veras no primeiro semestre de 1759" (MARCIS, 2004, p. 213). Segundo Carvalho (2011, p. 350), "a partir de 1755 , as mais populosas aldeias indígenas passaram a ser elevadas a vilas e os religiosos afastados da sua administração, após a expulsão dos jesuítas do Brasil e extinção das ordens religiosas sobre os índios, por Marquês de Pombal". A partir desse momento, passa a vigorar o denominado Diretório Pombalino, que, mesmo tendo sido revogado em 1798, permaneceu oficiosamente em vigor até 1845, quando foi promulgado o regimento das missões, único documento indigenista geral do império.
}

$\begin{array}{llllll}\text { (C) ETD- Educação Temática Digital } & \text { Campinas, SP } & \text { v.20 } & \text { n.3 } & \text { p. 718-740 } & \text { jul./set. } 2018\end{array}$ 
Com a criação da vila, a então igreja de Nossa Senhora da Escada foi elevada à condição de freguesia. A disposição das residências junto à igreja permaneceu como o centro do governo civil da vila formado pela Câmara e pelo diretor dos índios nomeado pelo Governador. A extensão de terras que compunham o aldeamento foi confirmada como termo da vila e patrimônio dos índios e de seus descendentes. Esse modo de estruturação da vila vigorou durante longo tempo e, consequentemente, foi apropriado pelos moradores indígenas, passando a se constituir como espaço de autonomia e de confirmação da identificação étnica (MARCIS, 2013).

Cabe ressaltar, como nos alertou Marcis (2013), a presença histórica dos Tupinambá em Olivença, o que nos ajuda a compreender a historicidade e a presença dos indígenas em Olivença e todo o movimento desencadeado durante o século XX em torno do reconhecimento étnico e na busca pela demarcação de seu território ancestral. Mesmo diante da negação, por parte do Estado e dos latifundiários, acerca da existência dos indígenas em Olivença, posto que buscavam se apropriar das terras indígenas, como de fato ocorreu, processo intensificado em fins do século XIX e nas primeiras décadas do século XX, - Diretório dos Índios e o Código de Posturas em Olivença, mesmo que de forma contraditória, acabaram por construir um sentimento de pertença entre os indígenas desta vila.

\begin{abstract}
Assim como o Diretório dos Índios, o Código de Posturas e outros instrumentos que visaram anular a identificação étnica dos índios de Olivença, também permitiram a utilização da mesma linguagem para a sua afirmação. No processo de reelaboração da identidade étnica, os moradores passaram a se assumir como "índios de Olivença" e eram vistos como tais pelos outros moradores e autoridades. Mesmo as definições generalizantes de "natural" ou "nativo" abarcavam o sentido da origem comum, de práticas culturais próprias e dos direitos tradicionais às terras do antigo aldeamento. Essa identidade foi constantemente reforçada nos discursos dos diretores, vereadores e juiz de órfãos, mesmo sob a concepção negativa e preconceituosa que expressavam ao ressaltarem aspectos como ignorância, ingenuidade. (MARCIS, 2013, p. 8).
\end{abstract}

No século $X X$, um dos eventos mais recentes na memória dos Tupinambá é o movimento instigado pelo Caboclo Marcelino (1924-1937), reconhecido como a "Revolta do Caboclo Marcelino"". O indígena resistiu à invasão de Olivença pelas elites que queriam construir uma ponte entre Ilhéus e Olivença, sobre o Rio Cururupe, no intuito de tornar Olivença uma área de veraneio para as famílias abastadas de Ilhéus (COUTO, 2008; UBINGER, 2012; LINS, 2007). Segundo Viegas (2007, p. 260), “o significado da revolta de Marcelino esteve associado a uma tentativa de contrariar essa usurpação das terras dos índios. A vila estava, pela primeira vez, ocupada pela burguesia fundiária (branca) e administrada por eles contra os interesses dos índios". A relação entre o território da vila e o da mata passa então a ser vital para assegurar a permanência dos Tupinambá na região.

\footnotetext{
${ }^{6}$ Para maiores informações sobre esse episódio vê os trabalhos e Lins (2007), Paraíso (2009) e Couto (2008).

(C) ETD- Educação Temática Digital Campinas, SP $\quad$ v.20 $\quad$ n.3 $\quad$ p. 718-740 jul./set. 2018
} 
O período de queda da produção do cacau na região do sul da Bahia nos idos de 1980, como consequência da proliferação da praga de "vassoura de bruxa", transformou o cenário da economia local levando à completa falência dos até então ricos proprietários rurais que ostentavam em suas fazendas estruturas físicas grandiosas (ROCHA, 2014). Neste mesmo período, os Tupinambá dão início ao movimento de reorganização interna e empreendem as primeiras ações em busca de reconhecimento étnico por parte do Estado Brasileiro, que serão intensificadas na década de 1990 e nos primeiros anos da década de 2000, a partir da constituição de novas alianças com outros povos indígenas, especialmente com os Pataxó, mas também com instituições indigenistas, a exemplo da Fundação Nacional do Índio - FUNAI, do Conselho Indigenista Missionário - CIMI e da Associação Nacional de Ação Indigenista - ANAí.

Diversas etnografias têm sido produzidas, nas últimas décadas, sobre os Tupinambá, em relação a diferentes temáticas, a exemplo do trabalho de Viegas (2007), que se tornou uma referência importante para os estudiosos, sobretudo entre os antropólogos que continuam a desenvolver pesquisas entre este povo. Sua etnografia se sustenta em uma antropologia da vida cotidiana e, nesse sentido, são acionados conceitos como socialidade, comensalidade, convivialidade e micro história que se tornam centrais para a compreensão do parentesco, das relações de gênero, dos afetos, da produção dos lugares que, no limite, como propõe a autora, atuariam na produção da pessoa Tupinambá, conceitos que se tornaram centrais para o tipo de análise que desenvolvemos em nossa tese.

As etnografias de Macedo (2007), Couto (2008), Ubinger (2012), Magalhães (2010), Mejía Lara (2012), Alarcon (2013) e Rocha (2014) representam algumas das pesquisas mais atuais que têm sido realizadas junto a esse povo e que buscam compreender distintos aspectos da socialidade Tupinambá, a exemplos de questões relacionadas à territorialidade e à religiosidade, aos processos de sociogênese que impulsionaram os Tupinambá em torno do reconhecimento étnico, especialmente a partir da década de 1990, às concepções nativas em torno da cultura e do "estar na cultura" e aos processos que são próprios ao fazer política entre esse povo. Mesmo que esses autores não tratem diretamente da escola, suas reflexões iluminam a compreensão acerca dela, uma vez que a construção e a busca por escola entre os Tupinambá, como demonstraremos, estão relacionados a processos mais amplos que envolvem o fazer política, o estar na cultura, à atualização do parentesco e à produção de aparentamento, à construção de um tipo de pessoa forte na cultura e às demandas e lutas em torno do território, às ações de retomadas já que é por meio desses vetores que se instauram formas de socialidades consideradas indígenas, Tupinambá.

$\begin{array}{llllll}\text { (C) ETD- Educação Temática Digital } & \text { Campinas, SP } & \text { v.20 } & \text { n.3 } & \text { p. 718-740 } & \text { jul./set. } 2018\end{array}$ 


\section{A CATEGORIA ESCOLA INDÍGENA NA BAHIA E OS TUPINAMBÁ}

As políticas educacionais voltadas aos povos indígenas da Bahia reverberam e produzem tensões, disputas, enfrentamentos e negociações que têm sido travadas em distintos espaços onde os indígenas se fazem presentes, a exemplo da própria Secretaria de Educação do Estado da Bahia e do Fórum Estadual de Educação Escolar Indígena. No caso específico dos Tupinambá, a tensão vivida nos últimos anos está relacionada, em grande parte, ao modelo de escola que os Tupinambá querem para si e a escola que os Estado pensa para eles e para as demais comunidades indígenas ${ }^{7}$.

Mesmo entendendo que entre os Tupinambá a construção de um projeto de escola tenha se dado anteriormente à responsabilização do Estado pela educação escolar entre este povo, no momento em que o Estado da Bahia começou a elaborar uma política de educação voltada para os povos indígenas (fruto das reivindicações desses povos e de parceiros da "causa indígena", a exemplo de indigenistas, Ongs e Universidade), os Tupinambá, nessa nova conjuntura, acionam e pressionam as estruturas do Estado, no sentido de que este passe a se responsabilizar pela educação escolar em seu território.

Como já dito, é a partir da Constituição Federal de 1988, mas sobretudo na década de 1990, que o Estado Brasileiro passa a normatizar, diante das demandas trazidas pelos povos indígenas, um modelo de educação assentado nos princípios da especificidade, da interculturalidade, da diferença e do bilinguismo. É nesse mesmo contexto que a política de educação para os povos indígenas foi descentralizada, a partir do Decreto Presidencial de no 26, de 1991, delegando aos estados e municípios, a partir da coordenação do Ministério da Educação, a responsabilidade pelo oferecimento de educação escolar (SILVA, 2013, 214; CARVALHO, 2007; COHN, 2005; GRUPIONI, 2008).

Foi a mobilização do Movimento Indígena da Bahia que potencializou a construção de uma política de educação escolar indígena diferenciada neste Estado, mesmo diante dos diversos problemas e tensões surgidas nesse processo de implementação, sobretudo no que

\footnotetext{
7 Por mais que o Estado da Bahia reconheça a categoria escola indígena em sua perspectiva específica, diferenciada e intercultural, o modo de funcionamento do Estado e, consequentemente, a implementação de uma política de educação escolar indígena tem se dado de modo nem sempre harmonioso, de forma a não cumprir o que determina a legislação em vigor. Por exemplo, não é raro a escola deixar de funcionar em virtude de problemas relacionados ao transporte escolar (este, quase sempre, é disponibilizado às comunidades indígenas com atrasos, inviabilizando o início do período letivo em tempo regular); ademais, a qualidade ruim do transporte é sempre motivo de queixas por parte dos Tupinambá. Atrasos nos salários de professores e demais funcionários da escola é muito recorrente e em muitos casos os indígenas são obrigados a paralisarem suas atividades.
}

$\begin{array}{llllll}\text { (C) ETD- Educação Temática Digital } & \text { Campinas, SP } & \text { v.20 } & \text { n.3 } & \text { p. 718-740 } & \text { jul./set. } 2018\end{array}$ 
diz respeito à organização, gestão e funcionamento das muitas escolas localizadas em território dos povos indígenas deste Estado ${ }^{8}$. Segundo Silva,

No caso do Estado da Bahia, os sistemas de ensino municipais e o sistema de ensino estadual não assumiram prontamente suas responsabilidades para com a política. Nos primeiros anos da década de 1990, quando a FUNAl cessou a contratação de professores, os representantes políticos indígenas, em articulação com este órgão, apresentaram essa demanda às prefeituras municipais. Como a demanda não foi atendida, alguns professores indígenas começaram a dar aulas voluntariamente, recebendo doações de pessoas das comunidades ou de organizações não governamentais. [...] Assim, as primeiras iniciativas de construção de um projeto político pedagógico próprio para as escolas indígenas surgem de professores indígenas, indigenistas e ONGs, fora do aparelho administrativo do Estado e dos municípios. Entretanto, ao longo das décadas de 1990 e 2000, criou-se na Bahia uma legislação sobre as escolas indígenas, pautadas nas leis federais sobre o assunto. (SILVA, 2013, p. 127-128).

A Educação Escolar Indígena na Bahia passou a ter um novo status a partir de 2003, quando foi realizada uma reestruturação organizacional da Secretaria de Educação em cumprimento às exigências do Ministério da Educação. O Decreto no 8.471/03 cria a categoria Escola Indígena no âmbito do Sistema Estadual de Ensino e a Resolução no 106/04, do Conselho Estadual de Educação, estabelece diretrizes e procedimentos para a organização e oferta da Educação escolar indígena. Antes desta determinação, os estudantes indígenas estudavam em escolas municipais ou estaduais próximas às aldeias, ou nas 19 escolas identificadas como indígenas que estavam inseridas no quadro das escolas rurais, sob a gerência da Coordenação de Ensino Fundamental da Secretaria de Educação SEC (SILVA, 2013; FERREIRA, 2011; SANTANA, 2007). Ademais,

Com a criação, em 2003, da Coordenação de Educação Indígena e do Campo no novo organograma, embora ainda compartilhando com outro segmento educacional que possui características e objetivos diferentes da escola indígena, começa-se a discutir na SEC o gerenciamento de uma escola que tenha seu planejamento, currículo e materiais didáticos produzidos a partir de contextos indígenas específicos. Uma das primeiras ações desta Coordenação foi a realização de visitas a algumas aldeias e um levantamento situacional das escolas indígenas e de suas demandas. Paralelamente, houve uma aproximação do setor com lideranças e professores indígenas baianos que já tinham iniciado o movimento de reivindicação por escolas nas áreas indígenas. A SEC passa então a participar e financiar o Fórum Estadual de Educação Escolar Indígena que existia desde 2000 como instância de interlocução entre os povos indígenas e o poder público, e com essa aproximação procura estruturar a Educação Escolar Indígena na Bahia. Foram criadas e organizadas várias escolas indígenas e, no final de 2003, contava-se com 46 escolas indígenas em funcionamento. (FERREIRA, 2011, p. 31-32).

\footnotetext{
8 Segundo dados da Secretaria de Educação, vivem na Bahia, atualmente, cerca de 37.000 indígenas, representando 16 grupos étnicos: Atikum, Kaimbé, Kantaruré, Kariri-Xocó, Payayá, Pankararé, Pankarú, Pataxó Hã Hã Hãe, Pataxó, Truká, Tumbalalá, Kiriri, Tupinambá (Tupinambá de Olivença e Tupinambá do Jequitinhonha), Tuxá, Xakriabá e Xukuru-Kariri. Quando confrontado com dados apresentados pelo Movimento Indígena da Bahia, o número de etnia tende a aumentar, ultrapassando mais de vinte povos.
}

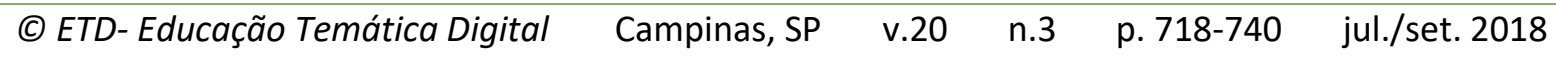


Em 2006, o Plano Estadual de Educação da Bahia estabeleceu diretrizes, metas e objetivos com a finalidade de subsidiar as políticas de educação para os próximos 10 anos, incluindo entre elas ações para as escolas indígenas. Ademais, estabelece que a Coordenação Estadual de Educação Indígena e do Campo é responsável, dentro da estrutura administrativa da SEC-BA, pela execução das políticas dirigidas a essas duas modalidades de educação. Em maio de 2007, criou-se a Coordenação Estadual de Educação Escolar Indígena, desvinculando-a da Coordenação de Educação do Campo, que fica sob responsabilidade de Rosilene Cruz Araújo, da etnia Tuxá, indicada pelo Fórum Estadual de Educação Escolar Indígena ${ }^{9}$. São criadas, ademais, coordenações em sete Diretorias Regionais de Educação (DIREC) em Itabuna, Eunápolis, Teixeira de Freitas, Paulo Afonso, Ribeira do Pombal, Serrinha e Ibotirama. As conquistas mais recentes se traduzem na construção do Território Etnoeducacional Yby Yara ${ }^{10}$ e na aprovação da Lei 18.629, em 2010, que instituiu a carreira de Professor Indígena no quadro do Magistério Público do Estado da Bahia, cujo desdobramento foi a realização do concurso para professores indígenas no primeiro semestre de 2014.

É neste movimento, entre as décadas de 1990 e 2000, que serão realizadas, no âmbito acadêmico, as primeiras pesquisas voltadas para a educação escolar entre os povos indígenas na Bahia, a exemplo de Cortês (1996, 2001), Souza (2001), César (2011), Silva (2006), Santana (2007) e outras que têm sido realizadas mais recentemente, a exemplo de Silva (2009, 2014), Ferreira (2011, 2013), Araújo (2010, 2011, 2013), Saraiva (2009), Chates (2011, 2013), Macedo (2009), César (2011), César e Silva (2013), Santana (2015), Bomfim (2012); outras, além das já citadas, mesmo sem tratarem diretamente da escola, acabam trazendo reflexões sobre a mesma, a exemplo de Miranda (2006, 2009), Carvalho (2007) e Sampaio $(2006)^{11}$.

O movimento indígena de organização dos atuais Tupinambá se configura desde os anos 1980, mas ganha corpo principalmente a partir do final dos anos de 1990 (já fizemos referência a esse movimento), quando uma mulher nativa, Núbia Batista da Silva, com formação escolar superior (graduação em Pedagogia pela Universidade Estadual de Santa Cruz, Ilhéus/BA) e ligada a uma organização não governamental de alfabetização

\footnotetext{
${ }^{9}$ O Fórum de Educação Escolar Indígena da Bahia, criado no processo da luta por uma educação escolar indígena específica, diferenciada, de qualidade, durante o primeiro curso do magistério indígena, tem sido um espaço do movimento dos professores indígenas para tratar das questões relacionadas à educação escolar no âmbito do Estado, o que tem possibilitado o diálogo entre as instituições governamentais e não governamentais, para a melhoria na implementação e execução da educação indígena. (BOMFIM, 2013, p. 248-249).

${ }^{10}$ Para mais informações sobre o processo de constituição do Território Etnoeducacional Yby Yara, vê César e Costa (2013).

${ }^{11}$ Os trabalhos de Silva (2016), Santos (2016) e Cruz (2016) dão continuidade às pesquisas sobre escolas indígenas na Bahia.
}

(C) ETD- Educação Temática Digital Campinas, SP $\quad$ v.20 $\quad$ n.3 $\quad$ p. 718-740 jul./set. 2018 
(CAPOREC ${ }^{12}$ ) passa a mobilizar as famílias de diversas localidades, que hoje compõe o perímetro da Terra Indígena Tupinambá de Olivença. É nesse contexto de mobilização e reorganização interna que a educação escolar indígena começa a ser pensada e construída de modo a atender às necessidades deste povo, buscando atuar em duas frentes: a luta pelo reconhecimento étnico e a retomada de seu território ancestral. O que se vislumbra, a partir desse novo contexto, é uma escola que seja produzida pelos e para os Tupinambá.

O projeto de educação escolar iniciado a partir de 1996, sob a liderança de Núbia Batista da Silva, ganha força na medida em que um grupo de professores começa a trabalhar voluntariamente para alfabetizar os moradores da aldeia. Estimulados por Núbia, essas professoras participaram do Coletivo de Alfabetizadores Populares da Região Cacaueira - CAPOREC que tinha proposta pedagógica fundamentada na obra de Paulo Freire, como outras propostas de educação voltadas para povos indígenas da Bahia, a exemplo dos índios Kiriri, como demonstrou Cortês (1996), e consistia nos seguintes passos: primeiro, a identificação e motivação das famílias da comunidade; segundo, o levantamento das expectativas dos alfabetizadores; terceiro, o trabalho partindo das histórias de vida (SILVA, 2006). Assim, ao estudar e problematizar a realidade, as questões étnicas vieram à tona nas histórias de vida dos alfabetizadores e das alfabetizadoras que foram se somando ao movimento. Ao se assumirem indígenas, muitos alfabetizadores integram-se às atividades de formação e articulação política que preparavam as atividades paralelas à Comemoração dos 500 anos do Descobrimento do Brasil. Essa participação proporcionou ao grupo maior experiência e conexão com os demais povos indígenas, evidenciando a necessidade da definição étnica, já bem retratado por Viegas (2007), Ferreira (2011, 2013), Magalhães (2010) e Alarcon (2013). Nesse sentido,

\begin{abstract}
Esse movimento, protagonizado por Núbia e alguns outros professores, contribuiu sobremaneira na organização da comunidade para o reconhecimento étnico pela Fundação Nacional do Índio (FUNAI), em 2002, e a identificação do território Tupinambá de Olivença, atualmente em processo, com a publicação do relatório preliminar de demarcação das terras pela FUNAI, em 20 de abril de 2009, com área proposta de 47.376 ha, abrangendo os municípios de Ilhéus, Buerarema e Una. (MESSEDER e FERREIRA, 2010, p. 189).
\end{abstract}

Sob orientação de Núbia Batista e Pedrísia Damásio ${ }^{13}$ (umas das professoras que fazem parte desse movimento inicial) foram ensaiados os primeiros passos para a criação de uma escola na aldeia. Para isso, foram realizadas muitas reuniões itinerantes pelas comunidades, forjando-se condições de mobilização da população para a reafirmação étnica e sua organização enquanto índios, da mesma forma em que vai se discutindo a importância de uma escola que indígena, Tupinambá, e que estivesse a serviço da "afirmação da

\footnotetext{
${ }^{12}$ CAPOREC - Coletivo de Alfabetizadores Populares da Região Cacaueira, ONG institucionalizada em 05/09/96, mas que vem atuando na educação de jovens e adultos desde 1992.

13 É com Pedrísia, na região de Sapucaeira, em um espaço improvisado, que começa o processo de escolarização com prática pedagógica diferenciada, mesmo antes da construção do atual colégio.
}

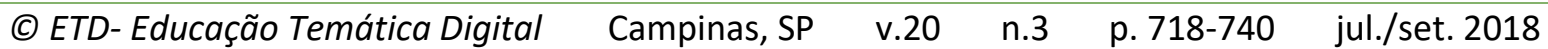


identidade, da busca por direitos e da valorização da cultura", como ouvi muitas vezes das professoras que fizeram parte desse movimento inicial, a exemplo de Pedrísia, Rosilene e Jesuína. Em relação a esse processo, afirma Magalhães:

\begin{abstract}
Concomitante ao diálogo que se criava com entidades indigenistas, Núbia passou a visitar assiduamente as comunidades rurais de Olivença a propósito das atividades de alfabetização promovido pelo CAPOREC, inicialmente contando com o apoio financeiro da FASE. Três núcleos de alfabetização foram criados naquela região: Sapucaieira, Acuípe e Olivença. As aulas [...] não se restringiam ao ensino do alfabeto para leitura e escrita, mas, sobretudo, se convertiam em mecanismo de defesa daquelas famílias que já haviam perdido território por desconhecerem seus direitos. Os conteúdos das disciplinas abarcavam um conjunto de temas relacionados à história da região, ou seja, tratavam, de algum modo, da história das inúmeras gerações de famílias que viveram e vivem em Olivença e comunidades próximas. (MAGALHÃES, 2010, p. 49-50).
\end{abstract}

Segundo Ferreira (2013, p. 290), “em 2000, Núbia fez um levantamento minucioso das demandas de alunos e professores que poderiam atuar, apesar de alguns não terem formação adequada, e organizou 19 núcleos escolares espalhados na região de Olivença". Ademais, conforme Magalhães (2010), o objetivo central do grupo de professoras indígenas consistia em reunir os integrantes da aldeia, para empreenderem seus direitos e lutarem pela educação escolar indígena na aldeia.

Após o reconhecimento oficial pela FUNAl em 2002 e diante do crescimento da demanda por escola, em 2003 foi criada a Escola Estadual Indígena Tupinambá de Olivença - EITO, no âmbito da Secretaria de Educação do Estado da Bahia, que a partir desse momento se responsabiliza pela educação escolar, contratando professores, além de comprometer-se em construir a escola, posto que até aquele momento as salas de aula funcionavam em espaços improvisados e precários. A escola é construída e inaugurada em 2006, cuja sede fica na Comunidade de Sapucaeira. Neste ano, segundo o Censo Escolar, atendia-se a 325 estudantes do pré-escolar, da 1a a 4ạ série e Educação de Jovens e Adultos (FERREIRA, 2013). Tive acesso ao número de estudantes, através do Sistema de Gestão Escolar - SGE - do Estado da Bahia, entre os anos de 2010 e $2014^{14}$. Conforme o SGE, em 2010, estudaram na escola Estadual Indígena Tupinambá de Olivença novecentos e cinquenta e um estudantes (951); em 2011, setecentos e vinte e um estudantes (721); em 2012, oitocentos e trinta e um (831); em 2013, setecentos e vinte e nove (729) e em 2014 novecentos e setenta e quatro (974).

\footnotetext{
${ }^{14}$ Esses mesmos dados me foram passados pela diretora da escola Cleusa Pinto, no momento em que realizava a pesquisa de doutorado.
}

(C) ETD- Educação Temática Digital Campinas, SP $\quad$ v.20 $\quad$ n.3 $\quad$ p. 718-740 jul./set. 2018


Em 2009, por exemplo, existiam 20 salas nucleadas ${ }^{15}$, contrastando com 17 Núcleos ${ }^{16}$ em 2014. Novas retomadas implicam em construção de novos Núcleos; da mesma forma, quando ocorrem reintegração de posse em áreas de retomadas, núcleos são desativados. A diminuição dos Núcleos em 2014 esteve relacionada aos conflitos que se acirraram no território em 2013, entre os indígenas e os grandes proprietários da região, fazendo com que famílias não indígenas, diante do agravamento das tensões, se deslocassem para outras localidades (a exemplo de outras áreas de retomadas ou para Olivença), provocando a diminuição do número de alunos e, portanto, o fechamento de alguns núcleos, conforme nos relatou a diretora da escola Cleusa Pinto.

Cabe ressaltar, ademais, que a escola indígena é frequentada por estudantes de famílias não indígenas que habitam o território, o que tem sido, para alguns professores e lideranças, motivo de preocupação. Por outro lado, conhecemos estudantes que, diante do envolvimento com a "cultura na escola" vão se tornando "um pouco Tupinambá", como ouvimos certa vez de alguns desses estudantes. Em muitos intercâmbios que a escola realiza com instituições externas, a exemplo de escolas do município de Ilhéus, com a Universidade Estadual de Santa Cruz, com um quilombo localizado em Itacaré, esses estudantes participam ativamente. Ouvimos de um estudante não indígena, em Sapucaeira, que o que mais gostava na escola era "a parte da cultura". Ouvimos, também, de muitos professores, que um dos grandes problemas que a escola enfrenta está relacionado ao fato de que alguns desses estudantes não indígenas pouco se envolvem com as questões da cultura. Acompanhamos uma reunião com caciques, lideranças e professores, em 2012, realizada na escola em Sapucaeira, cuja pauta era discutir a presença de não indígenas na escola. Ao final da reunião, mesmo diante das ponderações, decidiu-se pela continuidade destes estudantes. Um dos professores presentes elaborou o seguinte argumento: "a gente não pode reproduzir o mesmo preconceito dos não indígenas em relação a nós".

\footnotetext{
${ }^{15}$ Núcleo de Olivença; Núcleo de Águas de Olivença; Núcleo de Tucum; Núcleo de Itapoã; Núcleo de Lagoa do Mabaço; Núcleo de Mamão; Núcleo de Acuipe de Baixo; Núcleo de Acuipe do Meio I; Núcleo de Acuipe do Meio II; Núcleo de Santana I; Núcleo de Santana II (Aldeia Abaeté); Núcleo de Sant'aninha I; Núcleo de Sant'aninha II; Núcleo de Serra do Serrote; Núcleo de Serra Negra; Núcleo de Serra das Trempes I; Núcleo de Serra das Trempes II; Núcleo de Retomada de Coqueiros; Núcleo de Acuipe de Cima; Núcleo de Jairí.

${ }^{16}$ Núcleo Katuana; Núcleo de Águas de Olivença; Núcleo do Tucum; Núcleo do Itapoã; Núcleo do Mamão; Núcleo do Acuípe de Baixo; Núcleo do Acuípe do Meio I; Núcleo do Acuipe do Meio II; Núcleo do Abaeté; Núcleo do Santananinha; Núcleo da Serra Negra; Núcleo da Serra das Trempes II; Núcleo do Acuípe de Cima; Núcleo da Taja Jairy; Núcleo do Gravatá; Núcleo do Maruim; Núcleo do Tamandaré. Destes, somente os Núcleos de Serra das Trempes II, Maruim, Tamandaré, Abaeté, Acuípe do Meio I, Mamão e Katuana, funcionavam nos turnos matutino e vespertino; o Núcleo de Itapoã funcionava nos três turnos. Os demais, só funcionavam em um turno.
}

$\begin{array}{llllll}\text { (C) ETD- Educação Temática Digital } & \text { Campinas, SP } & \text { v.20 } & \text { n.3 } & \text { p. 718-740 } & \text { jul./set. } 2018\end{array}$




\section{4 “A LETRA É A MESMA, MAS A CULTURA É DIFERENTE”}

Ouvimos a expressão "a letra é a mesma, mas a cultura é diferente" em conversas que tivemos com dona Lourdes Tupinambá, anciã que reside na comunidade Tucum. Sempre que iniciávamos conversas sobre a educação escolar, era muito comum dona Lourdes repetir essa afirmação, sobretudo quando a questionava sobre a importância da educação para seus netos que estudavam na Escola Estadual Indígena Tupinambá de Olivença. Dona Lourdes sempre demonstrou muita preocupação com essa questão, inclusive com o Núcleo da referida escola que funciona nesta comunidade. As preocupações estavam relacionadas, sobretudo, à ausência do professor ${ }^{17}$ para ministrar as aulas, o que era, também, motivo de preocupação para muitos pais e mães desta comunidade, como pude observar.

A ausência do professor comprometia o bom funcionamento das aulas neste Núcleo, provocando tensões ${ }^{18}$ entre os moradores desta comunidade, em especial entre os pais que tinham crianças que ali estudavam, em relação à qualidade da educação por ele ofertado (a falta de qualidade é quase sempre entendida como não ter aula, diante da ausência do professor). Ouvimos de muitos pais tais preocupações, inclusive afirmando que teriam tirado seus filhos da escola da comunidade em virtude desta ausência.

O sentido dado por dona Lourdes à educação escolar, a partir de sua fala "a letra é a mesma, mas a cultura é diferente", é marcado por dois entendimentos, não excludentes, sobre os quais vale a pena refletir: o fato de a letra ser a mesma, ou seja, a compreensão de um código que vale tanto para a escola indígena quanto para a escola não indígena, justificava-se, para dona Lourdes, na necessidade do aprendizado da leitura, da escrita, do tornar-se alfabetizado porque, segundo ela, "nossos estudantes precisam se tornar sabidos,

\footnotetext{
${ }^{17} \mathrm{~A}$ ausência do professor às aulas no referido Núcleo era em decorrência do fato de que este assumia outras funções na comunidade, como a de cacique (termo nativo atribuído às lideranças políticas dos Tupinambá), o que fazia com que este tivesse que atender a outras demandas da comunidade, como participar de reuniões com os órgãos do governo, dentre outras coisas. Sobre essa questão, presenciei muitos debates em torno dessa dupla condição: "ser professor e cacique". Alguns argumentavam de forma contrária, justificando que um professor não poderia assumir a função de cacique, tendo em vista que a sobrecarga de trabalho que a função exige impediria, em muitos momentos, que este estivesse em sala de aula, o que prejudicaria, consequentemente, o bom andamento da escola, do ensino e da aprendizagem dos estudantes. Outros, que se posicionavam a favor, traziam como justificativa o fato de que a função de cacique não é remunerada. Um professor e cacique, portanto, necessitaria deste salário para sobreviver. Justificavam, ainda, como forma de resolver "suas ausências em sala de aula" a necessidade deste ter um professor(a) ajudante (auxiliar), que nos momentos de sua ausência assumiria as funções em sala de aula, não prejudicando os estudantes. Na prática, a situação é mais delicada, posto que ter um "professor ajudante" implicava na contratação, por parte do Estado, de mais um profissional, o que nem sempre é atendido, mesmo diante da necessidade.

${ }^{18}$ Essas tensões foram presenciadas durante uma reunião em que participei, organizada pela diretora Cleusa Pinto, com os pais e lideranças desta comunidade, com o objetivo de ouvir os pais no que dizia respeito aos problemas enfrentados pela educação naquele Núcleo, sobretudo em relação às ausências do professor às aulas. As mesmas queixas em relação a este problema ouvi em outros momentos em que estive na comunidade, conversando com os pais, estudantes e dona Lourdes.
}

(C) ETD-Educação Temática Digital Campinas, SP $\quad$ v.20 $\quad$ n.3 $\quad$ p. 718-740 jul./set. 2018


muito mais do que os outros" (os não indígenas), tendo em vista que, por muito tempo, sobretudo em passado não muito remoto, os Tupinambá perderam suas terras por não saberem ler, como costumam afirmar; contudo, não basta aos Tupinambá uma escola igual à dos não indígenas, justamente porque, se a letra é a mesma, a cultura é diferente. Nesse sentido, não vale qualquer escola, posto que é preciso uma que valorize a cultura Tupinambá e suas tradições e que, no limite, fortaleça-os na cultura. Nesses termos, uma cultura diferente deve produzir uma escola diferente, ao menos do ponto de vista ideal e diante das necessidades de afirmação identitária e de valorização cultural que se colocam para os Tupinambá. Ademais, os Tupinambá dizem que a escola é importante porque é uma forma de "ficar mais sabido", uma forma de defesa contra os brancos, geralmente expressam em frases do tipo "no passado perdemos nossas terras porque muitos de nossos parentes não sabiam ler e escrever; nossos parentes assinavam um papel e perdiam suas terras; outras vezes, trocavam a terra por qualquer coisa, a exemplo de cachaça", parecem assinalar para uma compreensão mais alargada da escola no contexto atual, não limitada ao ensino do "ler e escrever". Nesse sentido, o tornar-se sabido implica, através e pela escola, no aprendizado da cultura, da memória e da tradição; implica no tornar-se Tupinambá forte, no estar na cultura, no ser guerreiro. Tornar-se sabido é uma relação que envolve diferentes experiências que são potencializadas na/pela escola e em tudo o que ela proporciona.

A escola Tupinambá é também espaço de disputa, de produção de prestígio, de diferenças; umas das primeiras medidas, quando surge um novo cacicado, é criar escola (escolas produzem caciques e caciques produzem escola; estes produzem professor ${ }^{19}$ ). Nesse "ato de fazer escola", estão em jogo disputas por emprego e inúmeros cargos que surgem a partir da escola, mas não somente isso: a escola acaba por fortalecer laços, atualizando o parentesco, produzindo alianças, tanto internas quanto externas.

A escola, sendo o "lugar da cultura", como afirmam os Tupinambá, tende a fortalecêla, afirmá-la, mas também produzi-la. Segundo a cacique Jamapoty, em fala direcionada aos professores e funcionários do Colégio Estadual Indígena Tupinambá de Olivença, na semana Pedagógica de 2012, escola é "espaço de parentes, uma segunda casa. É o lugar onde se preparam lideranças para continuarem nossas lutas". Em outra ocasião, em dezembro de 2011, em reunião para avaliar a trajetória da educação escolar no decorrer do ano letivo, o professor Marcelo (à época professor de cultura) afirma: "A cultura precisa ser vivenciada. No crescimento da cultura, todo mundo precisa sentar junto para decidir; a cultura não é de um professor. Precisamos crescer todos juntos".

Para os Tupinambá estar na e ter a cultura é algo que implica constante investimento, produção, na medida em que o contrário provoca, tanto interna quanto externamente, acusações e desconfiança quanto ao ser mais ou menos indígena. A cultura é um modo de operar relações e, nesse sentido, ela precisa ser ensinada, aprendida,

${ }^{19}$ É muito comum ouvir a expressão "aquele professor pertence à cacique Jamapoty".
(C) ETD-Educação Temática Digital
Campinas, SP
v.20 n.3
p. $718-740$
jul./set. 2018 
experienciada, vivenciada, encorporada tanto no ambiente escolar como em outros contextos e relações; a cultura é "autopoiese" (GOW, 1997) e, nisso, precisa ser constantemente produzida, atualizada.

Na escola, a cultura precisa ser produzida por todos os Tupinambá, tarefa que não é fácil e que sempre gera discussões, desentendimentos, ponderações e reflexões sobre a escola, o diferenciado e a interculturalidade. Sobre a presença de um professor de cultura na escola as opiniões variam, mas de forma geral, sua presença parecer ser indispensável para a valorização da cultura, não só por parte dos alunos, mas também dos professores, lideranças e especialmente caciques. Essas tensões surgiam nos momentos de avaliação da escola, nos encontros pedagógicos, em conversas que tínhamos com professores, lideranças, caciques e estudantes.

Nos encontros e reuniões pedagógicas as questões relacionadas à cultura e sua valorização dentro da escola eram sempre recorrentes ${ }^{20}$. Nesses encontros, pouquíssimas vezes presenciei discussões relacionadas "à qualidade da educação" ou sobre o "ensino e aprendizagem" dos estudantes (questões sempre recorrentes nas falas de professores das escolas não indígenas). Tudo costumava girar em torno da cultura, da ausência do professor de cultura na escola e das relações tensas que os Tupinambá vivenciam com o Estado. Sobre a ausência do professor de cultura na escola presenciei diferentes falas:

A ausência do professor de cultura na escola está fazendo com que os meninos deixem de praticar o Poranci [ritual praticado pelos Tupinambá]. Se o professor não vai para a escola, como é que se vai trabalhar essa cultura? (Vice-diretor Erlon, reunião Pedagógica). Muitos professores deixaram de dançar o ritual e com isso enfraqueceram a comunidade (Liderança Jacarandá, reunião pedagógica).

A escola e tudo o que ela possibilita, em termos de "produção de novos Tupinambá" (e não somente de identidades sociais), mais "fortes na cultura", como eles dizem, parece acenar para essas possibilidades: na "produção de novos Tupinambá", emergem, também, "pessoas Tupinambá", "tradições indígenas" "educação indígena" que, necessariamente, não se contrapõem à educação escolar, mas antes, buscam marcar diferenças, que se tornam compreensíveis a partir da escola. Como afirma Gallois (2007, p. 100) "regimes culturais são passíveis de mudanças, geradas por transformações em série e pela complexificação das dinâmicas de transmissão cultural". Além disso, segundo a autora, "nesses processos, elas [as comunidades indígenas] não só criam novos objetos como constroem a si mesmas, enquanto sujeitos políticos e ativos agentes da mudança" (2007, p.

\footnotetext{
${ }^{20}$ Analisando as Atas das reuniões pedagógicas e outros encontros realizados na escola, as discussões sobre a cultura na escola estão sempre presentes, nas falas de professores, lideranças e cacique. 0 grande chamado é para que se valorize a cultura. Da mesma forma, os discursos presentes nessas Atas, quando se relacionam "a pouca vivência da cultura na escola", sinalizam para consequências internas e externas, como o enfraquecimento do movimento, da luta pelo território e da escola como um todo.
}

(C) ETD-Educação Temática Digital Campinas, SP $\quad$ v.20 $\quad$ n.3 $\quad$ p. 718-740 jul./set. 2018


96). Do mesmo modo, segundo Sahlins (2004) é nesta "invenção da tradição de inventar" que vão se constituindo as culturas indígenas.

Uma das formas que a escola encontra para manter relações atualizadas entre parentes, sobretudo entre os que estão dispersos pelas comunidades é realizar "aulas de campo", onde os alunos são levados para essas comunidades, muitas delas áreas de retomadas, no sentido de que possam compreender os processos de luta pela demarcação do território e, da mesma forma, visitar parentes e ouvir as histórias contadas pelos anciãos.

Acompanhamos muitas dessas aulas de campo e, por isso, traremos como exemplo uma dessas aulas, realizada em uma área de retomada intitulada Taba Jairy, em que foram realizadas diversas atividades, como andar por trilhas na mata (atravessando a Morada dos Encantados), banho de rio, jogos entre os estudantes e professores, contação de histórias com os anciãos da comunidade, atividades que se estenderam durante todo o dia. Além disso, como forma de "fortalecer os estudantes na cultura", os professores prepararam giroba ${ }^{21}$ para que estes pudessem tomar. Segundo Nete, professora de cultura na escola sede em Sapucaeira,

A escola é o fortalecimento da multiplicação da cultura pelos alunos. Não é que os alunos têm que deixar sua cultura lá da comunidade para só aprender aqui na escola. Mas o que tem parecido é que o centro da cultura é a escola. A escola não pode esquecer que ela é também responsável pelo fortalecimento da cultura desses alunos, por isso que eu tenho feito meus horários, pegando esses alunos para esse trabalho; têm os dias, tem horário. Por que têm os dias e tem os horários? Porque eles também precisam dos conhecimentos políticos, porque se não mais tarde eles não vão saber lá fora reivindicar a defesa dos seus direitos. Os valores são importantes, a gente não pode abandonar nunca, porque é um conhecimento do dom, da natureza que nosso Deus Tupã já nos deu e os encantos da mata. Mas o saber político pertence à caneta e ao papel. Por isso os estudantes precisam saber, se não pode acontecer o que ocorreu antes; os nossos mais velhos perderam muito de seus territórios para os fazendeiros por não saberem o que estavam assinando, por não saberem o que estavam fazendo, por não saberem o quanto de dinheiro estavam recebendo; tudo isso pela falta de conhecimento dos saberes políticos; muitos de nossos mais velhos perderam muito de sua cultura também por isso, muitos venderam pau-brasil sem saber o que estavam fazendo. Nossos meninos e meninas precisam desse conhecimento para esse fim, sem

21 “A preparação da giroba pode ser feita por várias mulheres. Inicia-se com a raspagem do aipim, que é de seguida colocado numa panela a cozer no fogo, até que amoleça. Deixa-se depois esfriar e verte-se num pilão ou um recipiente de alumínio. Os Tupinambá preferem o pilão de madeira, mas nem sempre as unidades domésticas possuem um pilão suficientemente grande para amachucar a quantidade mínima de vinte litros de giroba que se faz de cada vez. À medida que se vai pisando o aipim, junta-se água, sendo necessário ser bastante vigoroso nesta tarefa porque o aipim, depois de cozido, deita uma goma que vai grudando a massa ao tacho - tarefa facilitada com o pilão, porque a massa se descola da madeira. A massa volta então ao fogo para ligar, após o que é vertida para uma vasilha. Este é o momento crucial do processo, pois é neste repouso que a bebida vai fermentar. $\mathrm{O}$ fato do recipiente ser de barro ou de no passado se verter a bebida em cabaças de grandes dimensões (sobre as quais falaremos mais à frente) são os diversos elementos implicados na fermentação. Os Tupinambá de Olivença associam a maior fermentação da bebida ao sabor mais amargo, isto é, “azedo" e por isso falam em "giroba doce" e "giroba azeda". (VIEGAS, 2006, p.161-162).

(C) ETD-Educação Temática Digital Campinas, SP $\quad$ v.20 n.3 $\quad$ p. 718-740 jul./set. 2018


esquecer que precisam do fortalecimento da identidade, do que somos nós, povos nativos (Entrevista realizada no museu da Escola Indígena, em outubro de 2011).

Para Renildo, cacique da retomada do Mamão, "o resgate da aldeia vai se dando com a construção da escola". Essa fala é central e aponta os diferentes caminhos que explicam o movimento que expande a escola por todo o território, movimento este que experimenta tensões, conflitos, rupturas, já que envolve disputas em torno desta. As escolas, portanto, atuam em defesa do território, já que atraem e fixam famílias nestas áreas, que investirão na produção de uma nova aldeia e de novos lugares, neste movimento em que se "retoma" parentes, território, ao mesmo tempo em que se atua em defesa destes. A luta que os Tupinambá empreendem em defesa do território é a mesma que se volta para produzir e manter suas escolas. Nesse sentido, como sugeriu Susana Viegas, no momento da arguição da tese (2015), "lutar envolve princípios éticos e esforço sobre o mundo" e, do mesmo modo, "lutar está relacionado à ideia de Tupinambá forte na cultura. Estar na cultura passa por experimentar a cultura, através das ligações intersubjetivas".

Outro aspecto não menos importante é que a escola tem produzido um tipo de enfrentamento mais direto com o Estado, legitimando lutas e produzindo novas demandas. Construir escolas tem sido, inclusive, uma forma de negociar com o Estado, posto que é muito comum ouvir, quando os Tupinambá reclamam a construção de novas Núcleos, a seguinte posição por parte dos que representam o Estado, a exemplo da Secretaria de Educação: "não podemos construir escolas em áreas de retomada, já que o território não foi ainda homologado". No entanto, os Tupinambá continuam construindo e expandindo suas escolas, produzindo novas alianças e fortalecendo o movimento indígena. Antes que o Estado reconhecesse a Escola dos Tupinambá, estes já se empenhavam em sua construção, inclusive como meio de atuar frente ao Estado. Não é à toa quando dizem que "tudo começou com a escola".

Construir escolas implica na construção de novas rotas no território Tupinambá, que além de fazer a escola funcionar, possibilitam a circulação de pessoas entre diferentes comunidades, à visitação entre famílias e, consequentemente, um maior controle sobre o próprio território e maior vigilância sobre áreas e espaços que ainda estão sob o controle de não indígenas. "Com as escolas nucleadas, as crianças já aprendem a conviverem já ali, a se fortalecerem, para quando tiverem que sair para rua, para cidade, já vão com conhecimento da comunidade", afirmou-nos uma professora da retomada do Mamão. 


\section{CONSIDERAÇÕES FINAIS}

Os Tupinambá fazem escola para resistirem e resistem fazendo escola. Estudar é resistir. Possibilidade, inclusive, para se manter no território, cuidando dos parentes. Se a escola produz novos postos de trabalho e, portanto, novas funções, novos empregos, que são, também, disputados internamente, a partir do modo como se faz política, que envolve a relação entre caciques, escola e professores, é verdade, também, que muitos permanecem no território, "fortalecendo a cultura, a luta, o movimento", porque tem a escola e as vantagens que esta oferece, a exemplo de emprego. Para algumas famílias, a possibilidade de renda vem da escola, do emprego que esta oferece. Outras, sem muita sorte, veem-se obrigadas a procurar emprego muito distante, a exemplo de São Paulo, em cidades próximas e na própria Ilhéus. Da mesma forma, famílias que vivem fora de Olivença, em outras cidades, ou mesmo em bairros de Ilhéus, são atraídas, "retomadas" para a luta junto ao movimento indígena.

Estudar é como fazer retomada, em duplo sentido: é resistência, diante dos perigos, das dificuldades que se enfrenta para chegar à escola. Alguns desses perigos são muito reais, sobretudo quando se instaura tensões mais agudas com os fazendeiros, dentro do próprio território. Ir à escola, nessas circunstâncias, é sempre perigoso. Ouvi de professores que nestas situações as crianças, especialmente as que precisam atravessar fazendas para chegarem à escola, têm que "esconder sua cultura, a pintura corporal, colares, tanga", como forma de não serem facilmente identificadas e, com isso, sofrerem ataques. Outras, ainda, segundo relato de um professor, "não querem chegar pintadas em casa porque tem medo do patrão, de serem expulsas da terra. Medo de sair da terra e não ter para onde ir". Por outro lado, estudar é "retomar", de forma sempre atualizada, através do que se aprende na e pela escola, a história dos antepassados, suas lutas, resistências; é produzir e "estar na cultura" como temos afirmado.

No passado, quando tinham que estudar em escolas não indígenas, alguns professores relataram os preconceitos e as dificuldades sofridas. Ter e fazer escola na aldeia, implica em "multiplicar a cultura, os valores, o conhecimento, para fortalecer os nossos estudantes", como afirmou a professora Nete. A escola, nesse novo contexto, produz torção e inversão de forças, já que está a serviço dos próprios Tupinambá, inclusive, diante da presença, hoje, de estudantes não indígenas em suas escolas.

\section{REFERÊNCIAS}

ALARCON, Daniela Fernandes. O retorno da terra: As retomadas na aldeia Tupinambá da Serra do Padeiro, sul da Bahia. 2013, 343f. Dissertação (Mestrado em Estudos Comparados sobre a América) - Instituto de Ciências Sociais, Programa de Pós-Graduação em Estudos Comparados Sobre as Américas, Universidade de Brasília, Brasília, 2013.

$\begin{array}{llllll}\text { (C) ETD- Educação Temática Digital } & \text { Campinas, SP } & \text { v.20 } & \text { n.3 } & \text { p. 718-740 } & \text { jul./set. } 2018\end{array}$


ARAÚJO, Rosilene Cruz de. Educação escolar indígena: breve histórico e perspectiva. In: César, América Lúcia Silva; Costa, Suzane Lima (Orgs.). Pesquisa e escola: experiências em educação indígena na Bahia. Salvador: Quarteto, 2013.

ARAÚJO, Rosilene Cruz de. Educação escolar indígena intercultural e a sustentabilidade territorial: Uma abordagem histórica sobre as Escolas Indígenas Capitão Francisco Rodelas e Pataxó Coroa Vermelha. 2011. Dissertação - (Mestrado em Educação e Contemporaneidade) Programa de Pós-Graduação em Educação, Universidade do Estado da Bahia, Salvador, 2011.

ARAÚJO, Rosilene Cruz de. Gerenciamento da educação escolar indígena, poder público e a relação com o movimento indígena: experiência e reflexão. Revista da FAEEBA - Educação e Contemporaneidade. v. 19, n. 33, jan./jun., 2010.

BERGAMASCHI, Maria Aparecida. Interculturalidade nas práticas escolares indígenas e não indígenas. In: PALADINO, Mariana; CZARNY, Gabriela (Orgs). Povos indígenas e escolarização: discussões para se repensar novas epistemes nas sociedades latino-americanas: Rio de Janeiro: Garamond, 2012.

BOMFIM, Anari Braz. Patxohã, língua de guerreiro: um estudo sobre o processo de retomada da língua Pataxó. 2012. 128f. Dissertação (Mestrado em Estudos Étnicos e Africanos) - Faculdade de Filosofia e Ciências Humanas, Universidade Federal da Bahia, Salvador, 2012.

BOMFIM, Anari Braz; SOUZA, Arissana Braz Bomfim de. O valor de uma escola para Kitok a partir da memória histórica Pataxó. In: César, América Lúcia Silva; Costa, Suzane Lima (Orgs.). Pesquisa e escola: experiências em educação indígena na Bahia. Salvador: Quarteto, 2013.

CARNEIRO DA CUNHA, Manuela. Políticas culturais e povos indígenas: uma introdução. In: CARNEIRO DA CUNHA, Manuela; CESARINO, Pedro (Orgs.). Políticas Culturais e povos indígenas. São Paulo: Cultura Acadêmica, 2014.

CARVALHO, Maria Rosário de. Os índios pedem passagem. Ciência e Cultura. São Paulo, v. 59, n. 2, 2007. Disponível em: http://cienciaecultura.bvs.br/scielo.php?pid=S000967252007000200014\&script=sci arttext. Acesso em: 8 jun. 2011.

CARVALHO, Maria Rosário de. "Índios do sul e extremo sul baianos: Reprodução demográfica e relações interétnicas". In: OLIVEIRA FILHO, João Pacheco de (Org.). A presença indígena no Nordeste: Processos de territorialização, modos de reconhecimento e regimes de memória. Rio de Janeiro: Contra Capa, 2011.

CÉSAR, América Lucia Silva. Lições de Abril: a construção da autoria entre os Pataxó de Coroa Vermelha. Salvador: EDUFBA, 2011.

CÉSAR, América Lúcia Silva; COSTA, Suzane Lima. Cartografia da educação indígena: relato de uma experiência de pesquisa intercultural e interétnica. In: César, América Lúcia Silva; Costa, Suzane Lima (Orgs.). Pesquisa e escola: experiências em educação indígena na Bahia. Salvador: Quarteto, 2013.

CHATES, Taíse de Jesus. A domesticação da escola realizada por indígenas: uma etnografia histórica sobre a educação e a escola Kiriri. 2011, 181f. Dissertação (Mestrado em Antropologia) - Programa de Pós-Graduação em Antropologia, Universidade Federal da Bahia, Salvador, 2011.

$\begin{array}{llllll}\text { (C) ETD- Educação Temática Digital } & \text { Campinas, SP } & \text { v.20 } & \text { n.3 } & \text { p.718-740 } & \text { jul./set. } 2018\end{array}$


CHATES, Taíse de Jesus. A domesticação da escola na perspectiva Kiriri. In: César, América Lúcia Silva; Costa, Suzane Lima (Orgs.). Pesquisa e escola: experiências em educação indígena na Bahia. Salvador: Quarteto, 2013.

$\mathrm{COHN}$, Clarice. Educação escolar indígena: para uma discussão de cultura, criança e cidadania ativa. Revista Perspectiva, Florianópolis, v. 23, n.02, pp. 485-515, 2005. Disponível em: https://periodicos.ufsc.br/index.php/perspectiva/article/view/9804. Acesso em: 13 de jun. 2013.

COHN, Clarice. A cultura na escola indígena. In: CARNEIRO DA CUNHA, Manuela; CESARINO, Pedro (Orgs.). Políticas Culturais e povos indígenas. São Paulo: Cultura Acadêmica, 2014.

COHN, Clarice; SANTANA, José Valdir Jesus de. Sobre escolas indígenas e sobre crianças indígenas: algumas reflexões. In: CÉSAR, América Lúcia Silva; COSTA, Suzane Lima (orgs.). Pesquisa e escola: experiências em educação indígena na Bahia. Salvador: Quarteto, 2013.

COHN, Clarice; SANTANA, José Valdir Jesus de. A antropologia e as experiências escolares indígenas. Revista Pós Ciências Sociais, v. 13, n. 25, São Luís: EDUFMA, 2016.

COLLET, Célia Letícia Gouvêa. Ritos de civilização e cultura: a escola bakairi. 2006, 391f. Tese (Doutorado em Antropologia Social) Programa de Pós-Graduação em Antropologia Social, Museu Nacional, Universidade Federal do Rio de Janeiro, Rio de Janeiro, 2006.

CÔRTES, Clelia Neri. A educação é como o vento: os Kiriri por uma educação pluricultural, 1996 Dissertação (Mestrado em Educação) - Programa de Pós-Graduação em Educação, Universidade Federal da Bahia, Salvador, 1996.

CÔRTES, Clelia Neri. Educação Diferenciada e Formação de Professores/as Indígenas: Diálogos intra e interculturais. 2001. 328f. Tese (Doutoramento em Educação), Programa de PósGraduação em Educação, Universidade Federal da Bahia, Salvador, 2001.

COUTO, Patrícia Navarro de Almeida. Morada dos encantados: Identidade e religiosidade entre os Tupinambá da Serra do Padeiro - Buerarema, BA. 2008, 169f. Dissertação (Mestrado em Ciências Sociais), Programa de Pós-Graduação em Ciências Sociais, Universidade Federal da Bahia, Salvador, 2008.

CRUZ, Aldrin da Costa. 0 índio no livro didático de história e a (des)construção de representações pelo professor indígena Pataxó. 2016, 192f. Dissertação - (Mestrado em Educação) - Programa de Pós-Graduação em Educação, Universidade Estadual de Feira de Santana, Feira de Santana, 2016.

D'ANGELIS, Wilmar da Rocha. Aprisionando sonhos: a educação escolar indígena no Brasil. Campinas, SP: Curt Nimuendajú, 2012.

FERREIRA, Mariana Kawall Leal. A educação escolar indígena: um diagnóstico crítico da situação no Brasil. In: SILVA, Aracy Lopes da. FERREIRA, Mariana Kawal Leal (Orgs.) Antropologia, História e Educação: a questão indígena e a escola. 2 ed. São Paulo: Global, 2001.

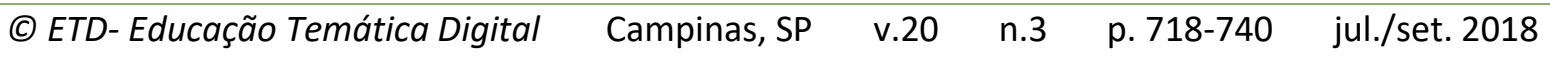


FERREIRA, Sonja Mara Mota. "A luta de um povo a partir da educação": Escola Estadual Indígena Tupinambá da Serra do Padeiro, 2011. Dissertação (Mestrado em Educação) Programa de Pós-Graduação em Educação, Universidade do Estado da Bahia, Salvador, 2011.

FERREIRA, Sonja Mara Mota. Escola Indígena Tupinambá da Serra do Padeiro. In: Césae, América Lúcia Silva; Costa, Suzane Lima (Orgs.). Pesquisa e escola: experiências em educação indígena na Bahia. Salvador: Quarteto, 2013.

GALLOIS, Dominique Tilkin. Materializando saberes imateriais: experiências indígenas na Amazônia Oriental. Revista de Estudos e Pesquisas, FUNAI, Brasília, v.4, n.2, dez. 2007.

GOW, Peter. O parentesco como consciência humana: o caso dos Piro. Mana - Revista de Antropologia Social, vol.3, n.2, 1997. Disponível em: http://www.scielo.br/scielo.php?script=sci arttext\&pid=S0104-93131997000200002. Acesso em: 12 out. 2009.

GRUPIONI, Luís Donisete Benzi. Quando a antropologia se defronta com a Educação: formação de professores índios no Brasil. Revista Pró-posições. V. 24, n. 2(71), maio/agosto, 2013. Disponível em: http://www.scielo.br/scielo.php?script=sci issuetoc\&pid=0103730720130002\&lng=pt\&nrm=iso. Acesso em: 5 de abril de 2014.

GRUPIONI, Luís Donisete Benzi. Olhar longe, porque o futuro é longe: cultura, escola e professores indígenas no Brasil. 2008. 240f. Tese (Doutorado em Antropologia Social), Programa de Pós-Graduação em Antropologia Social, Universidade de São Paulo, São Paulo, 2008.

LINS, Marcelo da Silva. Os vermelhos nas terras do cacau: A presença comunista no sul da Bahia (1935-1936). 2007. 255f. Dissertação (Mestrado em História) - Faculdade de Filosofia e Ciências Humanas, Universidade Federal da Bahia, Salvador, 2007.

LOPES DA SILVA, Aracy. Educação para a tolerância e povos indígenas no Brasil. In: GRUPIONI, Luís Donisete Benzi; VIDAL, Lux; FISCHMANN, Roseli (Orgs.) Povos indígenas e tolerância: construindo práticas de respeito e solidariedade. São Paulo: EDUSP, 2001.

MACEDO, Sílvia Michele. Educação por outros olhares: aprendizagem e experiência cultural entre os índios Kiriri do sertão baiano. 2009. 119f. Dissertação (Mestrado em educação) Programa de Pós-Graduação em Educação, Universidade Federal da Bahia, Salvador, 2009.

MACEDO, Ulla. A dona do corpo: um olhar sobre a reprodução entre os Tupinambá da Serra-BA. 2007, 196f. Dissertação (Mestrado em Ciências Sociais) - Instituto de Filosofia e Ciências Humanas, Universidade Federal da Bahia, Salvador, 2007.

MAGALHÃES, Aline Moreira. A luta pela terra como "oração": Sociogênese, trajetórias e narrativas do "movimento" Tupinambá. 2010, 151f. Dissertação (Mestrado em Antropologia Social), Programa de Pós-Graduação em Antropologia Social, Museu Nacional, Universidade Federal do Rio de Janeiro, Rio de Janeiro, 2010.

MAINARDI, Camila. Construindo proximidades e distanciamentos: etnografia Tupi Guarani da Terra Indígena Piaçaguera/SP, 2010a. Dissertação - (Mestrado em Antropologia Social), Programa de Pós-Graduação em Antropologia Social, Universidade Federal de São Carlos, São Carlos, 2010a.

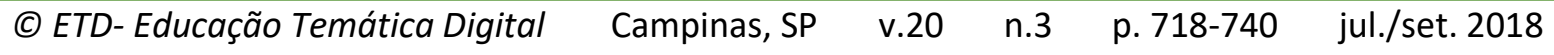


MAINARDI, Camila. O papel da escola no resgate cultural dos Tupi Guarani da Terra Indígena Piaçaguera-SP. Revista Pós em Ciências Sociais. v. 7, b. 14, jul./dez., 2010 b.

MARCIS, Teresinha. A "hecatombe de Olivença": Construção e reconstrução da identidade étnica - 1904. 2004. 163f. Dissertação (Mestrado de História), Programa de Pós-Graduação em História Social, Universidade Federal da Bahia, Salvador, 2004.

MARCIS, Teresinha. A integração dos índios como súditos do rei de Portugal: uma análise do projeto, dos autores e da implementação na Capitania de Ilhéus, 1758-1822. 2013, 309f. Tese (Doutorado em História) - Programa de Pós-Graduação em História Social, Universidade Federal da Bahia, Salvador, 2013.

MEJÍA LARA, Amiel Ernenek. "Estar na cultura": os Tupinambá de Olivença e o desafio de uma definição de indianidade no Sul da Bahia. 2012, 153f. Dissertação (Mestrado em Antropologia Social), Programa de Pós-Graduação em Antropologia Social, Universidade Estadual de Campinas, Campinas, 2012.

MESSEDER, Marcos Luciano Lopes; FERREIRA, Sonja Mara Mota. Educação escolar entre os Tupinambá da Serra do Padeiro: reflexões sobre a prática docente e o projeto comunitário. Revista da FAEEBA - Educação e Contemporaneidade, v. 19, n. 33, jan./jun., 2010.

MIRANDA, Sarah Siqueira. A Construção da Identidade Pataxó: práticas e significados da experiência cotidiana entre crianças da Coroa Vermelha. 2006, 111f. Monografia (Graduação em Ciências Sociais), Faculdade de Filosofia e Ciências Humanas, Universidade Federal da Bahia, Salvador, 2006.

MIRANDA, Sarah Siqueira. Aprendendo a ser Pataxó: Um olhar etnográfico sobre as habilidades produtivas das crianças de Coroa Vermelha, BA, 2009, 233f. Dissertação (Mestrado em Antropologia), Programa de Pós-Graduação em Antropologia, Universidade Federal da Bahia, Salvador, 2009.

PALADINO, Mariana; CZARNY, Gabriela. Interculturalidade, conhecimentos indígenas e escolarização. In: PALADINO, Mariana; CZARNY, Gabriela (Orgs). Povos indígenas e escolarização: discussões para se repensar novas epistemes nas sociedades latino-americanas: Rio de Janeiro: Garamond, 2012.

PALADINO, Mariana; ALMEIDA, Nina Paiva; Entre a diversidade e a desigualdade: uma análise das políticas públicas para a educação escolar indígena no Brasil dos governos Lula. Rio de Janeiro: Contra Capa Livraria/LACED - Museu Nacional/UFRJ, 2012.

PARAÍSO, Maria Hilda. Marcelino José Alves: de índio a caboclo, de "Lampião Mirim" a comunista, uma trajetória de resistência e luta no sul da Bahia, 2009. Anais do XXV Simpósio Nacional de História. Salvador, Bahia, 2009.

PEIRANO, Mariza. A favor da etnografia. Rio de Janeiro: Relume Dumará, 1995.

ROCHA, Cinthia Creatini da. "Bora vê quem pode mais": Uma etnografia sobre o fazer política entre os Tupinambá de Olivença (Ilhéus, Bahia). 2014. 303f. Tese (Doutorado em Antropologia Social) - Programa de Pós-Graduação em Antropologia Social, Universidade Federal de Santa Catarina, Santa Catarina, 2014.

$\begin{array}{llllll}\text { (C) ETD- Educação Temática Digital } & \text { Campinas, SP } & \text { v.20 } & \text { n.3 } & \text { p. 718-740 } & \text { jul./set. } 2018\end{array}$


SAHLINS, Marshall. Cultura na prática. Rio de Janeiro: UFRJ, 2004.

SAMPAIO, José Augusto Laranjeiras. O resgate cultural como valor: reflexões antropológicas sobre a formação de professores indígenas. In: Grupioni, Luiz Donisete Benzi (Org.). Formação de professores indígenas: repensando trajetórias. Brasília: Ministério da Educação/Secretaria de Educação Continuada, Alfabetização e Diversidade, 2006.

SANTANA, José Valdir Jesus de. A produção dos discursos sobre cultura e religião no contexto da educação formal: O que pensam/querem os Kiriri de sua escola?. 2007, 114f. Dissertação (Mestrado em Educação), Programa de Pós-Graduação em Educação, Universidade do Estado da Bahia, Salvador, 2007.

SANTANA, José. Valdir. Jesus. "A letra é a mesma, mas a cultura é diferente": a escola dos Tupinambá de Olivença. 2015. 241f. Tese (Doutorado em Antropologia Social) - Programa de Pós-Graduação em Antropologia Social, Universidade Federal de São Carlos, São Carlos, 2015.

SANTOS, Marcinéia Vieira Almeida. Práxis Pedagógicas e Saberes Culturais: Diálogos com as professoras Tupinambá de Olivença/BA. 2016, 137f. Dissertação (Mestrado em Educação Profissional), Programa de Pós-Graduação em Formação de Professores da Educação Básica, Mestrado em Educação Profissional, Universidade Estadual de Santa Cruz, Ilhéus-BA, 2016.

SARAIVA, Valuza Maria. Saberes indígenas: ensino fundamental na Bahia. 2009, $129 \mathrm{f}$.

Dissertação (Mestrado em Políticas Públicas, Gestão do Conhecimento e Desenvolvimento Regional) - Programa de Pós-Graduação em Políticas Públicas, Gestão do Conhecimento e Desenvolvimento Regional, Universidade do Estado da Bahia, Salvador, 2009.

SILVA, Carlos Rafael da. Políticas educacionais para povos indígenas no estado da Bahia. In: César, América Lúcia Silva; Costa, Suzane Lima (Orgs.). Pesquisa e escola: experiências em educação indígena na Bahia. Salvador: Quarteto, 2013.

SILVA, Carlos Rafael da. A implementação da política de educação para povos indígenas no estado da Bahia (2007 - 2014). 2014, 98f. Dissertação (Mestrado em Ciências Sociais), Programa de Pós-Graduação em Ciências Sociais, Universidade Federal da Bahia, Salvador, 2014.

SILVA, Núbia Batista da. Educação de Jovens e Adultos e a afirmação da identidade étnica do povo Tupinambá de Olivença - 1996 a 2004. 2006 Monografia (Especialização em Educação de Jovens e Adultos), Universidade Estadual de Santa Cruz, 2006.

SILVA, Paulo de Tássio Borges da. A Educação Escolar Indígena no Processo de Revitalização Cultural Pataxó na Escola Estadual Indígena Kijetxawê Zabelê. 2009, 100f. Monografia (Graduação em Pedagogia), Universidade do Estado da Bahia, 2009.

SILVA, Paulo de Tássio Borges. As Relações de Interculturalidade entre Conhecimento Científico e Conhecimentos Tradicionais Pataxó na Escola Estadual Indígena Kijetxawê Zabelê, 2014, 121f. Dissertação (Mestrado em Educação) - Programa de Pós-Graduação em Educação, Universidade Federal de Sergipe, Sergipe, 2014.

SILVA, William Gonçalves. Sentidos que os estudantes Pataxó da EJA conferem aos conhecimentos matemáticos para sua vida. 2016, 105f. Dissertação (Mestrado em Educação

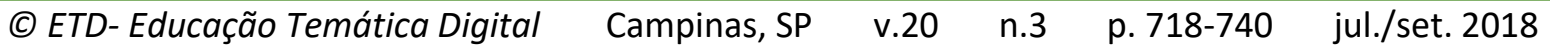


Científica e Formação de Professores), Programa de Pós-Graduação em Educação Científica e Formação de Professores, Universidade Estadual do Sudoeste da Bahia, Jequié-BA, 2016.

SOUZA, Ana Cláudia Gomes. Escola e reafirmação étnica: o caso dos Pataxó de Barra Velha, Bahia. 2001, 124f. Dissertação (Mestrado em Ciências Sociais), Programa de Pós-Graduação em Ciências Sociais, Universidade Federal da Bahia, Salvador, 2001.

SOUZA, Ana Cláudia Gomes. Revisitando a história da escola indígena: da escola para índios à escola indígena. In: CÉSAR, América Lúcia Silva; COSTA, Suzane Lima (Orgs.). Pesquisa e escola: experiências em educação indígena na Bahia. Salvador: Quarteto, 2013.

TASSINARI, Antonella Maria Imperatriz; COHN, Clarice. Escolarização indígena entre os Karipuna e Mebengokré-Xikrin: uma abertura para o outro. In: TASSINARI, Antonella Maria Imperatriz; GRANDO, Beleni Saléte; ALBUQUERQUE, Marcos Alexandre dos Santos. (Orgs.) Educação indígena: reflexões sobre noções nativas de infância, aprendizagem e escolarização. Florianópolis: UFSC, 2012.

TASSINARI, Antonella Maria Imperatriz. A educação escolar indígena no contexto do Antropologia brasileira. Ilha - Revista de Antropologia, v. 10, n. 1, p. 217-244, 2008. https://periodicos.ufsc.br/index.php/ilha/article/view/16328/0. Acesso em: 12 maio de 2010.

UBINGER, Helen Catalina. Os Tupinambá da Serra do Padeiro: Religiosidade e territorialidade na luta pela terra indígena. 2012, 189f. Dissertação (Mestrado em Antropologia), Programa de PósGraduação em Antropologia. Universidade Federal da Bahia, Salvador, 2012.

VIEGAS, Susana de Matos. Terra Calada: Os Tupinambá na Mata Atlântica do sul da Bahia. Rio de Janeiro: 7Letras, 2007.

VIEGAS, Susana de Matos. Nojo, prazer e persistência: beber fermentado entre os Tupinambá de Olivença (Bahia). Revista de História, 154, 2006.

http://www.journals.usp.br/revhistoria/article/view/19025/21088. Acesso em: 16 de ago. 2014.

VIEGAS, Susana de Matos. Socialidades Tupi: Identidade e experiência entre os índios-caboclos (Bahia/Brasil). 2003, 423f. Tese (Doutorado em Antropologia), Faculdade de Ciências e Tecnologia, Universidade de Coimbra, Coimbra/Portugal, 2003.

WEBER, Ingrid. Um copo de cultura: os huni kuin (Kaxinawá) do rio humaitá e a escola. Acre: EDUFAC, 2006.

\footnotetext{
' Revisão gramatical sob a responsabilidade dos autores
} 